TITLE:

\title{
Effects of water in water/phenol mixtures on liquefaction of Japanese beech as treated under subcritical conditions
}

\author{
AUTHOR(S):
}

Mishra, Gaurav; Saka, Shiro

\section{CITATION:}

Mishra, Gaurav ... [et al]. Effects of water in water/phenol mixtures on liquefaction of Japanese beech as treated under subcritical conditions. Holzforschung 2013, 67(3): 241247

\section{ISSUE DATE:}

2013-04

URL:

http://hdl.handle.net/2433/189836

\section{RIGHT:}

opyright of Holzforschung: International Journal of the Biology, Chemistry, Physics, \& Technology of Wood is the property of De Gruyter and its content may not be copied or emailed to multiple sites or posted to a listserv without the copyright holder's express written permission. However, users may print, download, or email articles for individual use 


\section{Effects of water in water/phenol mixtures on liquefaction of Japanese beech as treated under subcritical conditions}

\begin{abstract}
Japanese beech (Fagus crenata) has been liquefied by water-added subcritical phenol without a catalyst in a batch-type reaction vessel. The effect of water/phenol ratio was studied under conditions of various treatment times. The fractions soluble in phenol/water as well as the insoluble residues were characterized. Liquefaction kinetics was investigated assuming the validity of the first-order reaction rate law. The degree of phenolation was increased with increasing treatment times and water content in phenol/water solvent. Treatment at $270^{\circ} \mathrm{C}$ under 3.1 MPa pressure for $10 \mathrm{~min}$ with a water/phenol ratio of 25:75 gave the best liquefaction result. Various oligosaccharides derived from cellulose and hemicelluloses were found to be hydrolyzed and solubilized in the watersoluble portion.
\end{abstract}

Keywords: Japanese beech, noncatalytic liquefaction, subcritical phenol, water

*Corresponding author: Shiro Saka, Department of Socio-Environmental Energy Science, Graduate School of Energy Science, Kyoto University, Yoshida-honmachi, Sakyo-ku, Kyoto 606-8501, Japan, Phone/Fax: +81-75-753-4738, e-mail: saka@energy.kyoto-u.ac.jp

Gaurav Mishra: Department of Socio-Environmental Energy Science, Graduate School of Energy Science, Kyoto University, Kyoto, Japan

\section{Introduction}

The depletion of fossil fuel resources and climate change due to anthropogenic carbon dioxide emissions belong to the driving forces for the utilization of wood as a renewable carbon-neutral raw material (Saka 2006). Plant biomass, in general, will be an important part of sustainable energy systems in the future (Toor et al. 2011). A large body of literature describes many approaches, for example, the so-called biorefinery in connection to pulping, including the pretreatment of wood (Gütsch and Sixta 2011; López et al. 2011; Schütt et al. 2011; Testova et al. 2011) and enzymatic process steps (Hörhammer et al. 2011; Kirsch et al.
2011), just to mention a few. All methods are aimed at the fractionation of wood and a value-added evaluation of the isolated fractions. Wood liquefaction and fractionation in ionic liquids is also promising (Honglu and Tiejun 2006; Nakamura et al. 2010; Viell and Marquardt 2011). The same is true for the liquefaction of the whole biomass, which was developed based on the supercritical fluid technology (Minami and Saka 2003; Soria et al. 2008a,b). An approach based on hot-compressed water in a semiflow reaction system was described by Phaiboonsilpa and Saka (2011) and Phaiboonsilpa et al. (2011).

By means of the last mentioned technologies, the liquefied woody biomass can be converted into valuable chemicals and energy (McKendry 2002). Wood was converted by liquefaction in supercritical water to sugars, which were then fermented to alcohol (Adschiri et al.1993; Saka and Konishi 2001; Demirbas 2005). In the course of the process, cellulose, hemicelluloses, and lignin give rise to compounds with a low molecular weight. Lignintype degradation products are useful for the preparation of resins and adhesives, but various phenols such as coniferyl alcohol and sinapyl alcohol can also be isolated from the liquefaction products (Alma et al. 1998a; Ehara and Saka 2005).

Liquefaction can also be performed with phenolcontaining acidic or alkaline catalyst (Alma et al. 1995, 1998b; Maldas and Shiraishi 1997). Under a supercritical or subcritical condition, phenol as solvent is expected to have a low dielectric constant due to a cleavage of hydrogen bonds among phenol molecules. The reactions begin with the cleavage of ether bonds in lignin (Minami and Saka 2003) and continue with the degradation of hemicelluloses and finally of crystalline cellulose. Under conditions of high temperature and pressure, phenolysis takes place.

Water/phenol mixtures are expected to have benefits compared with the liquefaction with phenol alone. Phenol is almost insoluble in water under ambient conditions, but under supercritical conditions the water/phenol mixtures with low dielectric constant are no more phase-separated.

In the present study, the liquefaction behavior of Japanese beech (Fagus crenata) will be studied under 
a subcritical condition of water/phenol mixtures. The kinetic behavior of the liquefaction will also be in focus and the degree of phenolation will be reported.

\section{Materials and methods}

The sapwood of mature Japanese beech wood was air-dried, milled in a Wiley mill, and sieved. The fraction passed through 80 mesh was extracted with acetone (reagent grade; Nacalai Tesque, Inc., Kyoto, Japan), oven-dried for $12 \mathrm{~h}$ at $105^{\circ} \mathrm{C}$, and cooled down in a desiccator. Performance of the reactions: approximately $150 \mathrm{mg}$ oven-dried sample and $4.9 \mathrm{ml}$ phenol (reagent grade; Nacalai Tesque, Inc., Kyoto, Japan) plus a designated amount of water were fed into a $5 \mathrm{ml}$ batch-type cylindrical-shaped reaction vessel made of Inconel-625, to which thermocouple and pressure gauge were attached for the temperature and pressure measurements. Conditions of subcritical treatment: $270^{\circ} \mathrm{C} / 1.8-3.1 \mathrm{MPa} / 3-30 \mathrm{~min}$; heating by immersion into a molten salt bath of $\mathrm{KNO}_{3}$ (Parker Netsushori Kogyo Co., Ltd., Tokyo, Japan) preheated to $270^{\circ} \mathrm{C}$.

The reaction vessel was shaken inside the molten salt bath to maintain the homogenous mixing inside the vessel and for a proper heat transfer. The treatment time in the present study means the total heating time beginning from the insertion of the reaction vessel into the molten salt bath. After the treatment, the reaction vessel was quenched with water. The resulting reaction mixture was then filtered over polytetrafluoroethylene filters (Advantec, Tokyo, Japan) with $0.2 \mu \mathrm{m}$ pore size and $47 \mathrm{~mm}$ diameter under vacuum at ambient temperature, and the parts soluble in phenol and water were separated from the insoluble residue in phenol/ water.

The residue was washed properly with $\mathrm{MeOH}$ (reagent grade; Nacalai Tesque, Inc., Kyoto, Japan) to remove the phenol, and the obtained residue was oven-dried for $12 \mathrm{~h}$ at $105^{\circ} \mathrm{C}$, cooled down in a desiccator, and weighted. The contents of Klason lignin and acidsoluble lignin were determined according to Mishra and Saka (2010). The clear filtrate from the sulfuric acid hydrolysate was submitted to high-performance liquid chromatography (HPLC) for the determination of monomeric sugars. HPLC instrument: Shimadzu LC-10A system (Kyoto, Japan); column, Aminex HPX-87P (Bio-Rad, Tokyo, Japan) of $300 \times 7.8 \mathrm{~mm}$ dimensions; flow rate, $1.0 \mathrm{ml} / \mathrm{min}$; eluent, distilled water; RI detector, RID-10A; temperature, $40^{\circ} \mathrm{C}$. The contents of cellulose and hemicelluloses (wt\%) in the phenol-insoluble residue were then estimated based on the results of sugar analysis. The other calculations were done by means of Eqs. (1) and (2). The nonreacted, free phenol in the phenol-soluble portion was removed by bulb tube distillation unit under vacuum at $85^{\circ} \mathrm{C}$.

$$
\begin{aligned}
& \text { Phenol } \\
& \left.\left(\operatorname{Wood}_{\text {reaction vessel }}\right)\right] \\
& \operatorname{Wood}_{\text {phenolated }}(\%)=100 *\left[\left(\text { Phenol }_{\text {soluble }}-\text { Phenol }_{\text {free }}\right) /\right. \\
& \left.\left(\operatorname{Wood}_{\text {reaction vesse }}\right)\right]
\end{aligned}
$$

In the water-soluble fraction, cellulose and hemicellulose-derived products were also determined by HPLC as described above. The lignin-derived products were analyzed by HPLC: column, Cadenza CD C-18 (250×3 mm); flow rate, $1 \mathrm{ml} \mathrm{min}^{-1}$; eluent, $\mathrm{MeOH} /$ water 20:80 $\rightarrow 100: 0$; UV detector $(205 \mathrm{~nm})$; temperature, $40^{\circ} \mathrm{C}$.
Avicel PH-101 and xylan were purchased from Sigma-Aldrich, Inc. (Tokyo, Japan). Milled wood lignin (MWL) was prepared according to Björkman (1956).

\section{Results and discussion}

\section{Decomposition behavior}

Mishra and Saka (2010) observed that, at $270^{\circ} \mathrm{C} / 1.8 \mathrm{MPa} / 3$ min, most of the lignin and a part of hemicelluloses were liquefied and went into the phenol-soluble portion and almost all of the cellulose remained in the insoluble residue. While treating isolated xylan, cellulose, and MWL in a similar manner (Mishra and Saka 2012), the latter was almost three times more phenolated than the former. Lignin in the phenol-soluble portion is probably phenolated.

The parameter $270^{\circ} \mathrm{C} / 1.8 \mathrm{MPa}$ was maintained also in the present article and only the treatment time was varied. The reaction products were fractionated. Figure 1 shows the insoluble residues as a function of treatment time and the phenol/water ratios. The correlation seems to be an exponential logarithmic function; thus, the first-order reaction kinetics may be appropriate to describe the reaction mechanism (Mishra and Saka 2011).

The initial amount of the insoluble residue decreased rapidly and the soluble part increased. At a water/phenol ratio of 0:100, the phenol-insoluble residue was approximately $40 \%$ after $30 \mathrm{~min}$. Under the same conditions, but at the water/phenol ratios of 5:95, 10:90, and 25:75, the insoluble part diminished to $35 \%, 30 \%$, and $20 \%$, respectively. Probably, hydrolytic reaction in water is responsible for this finding (Pu and Shiraishi 1993).

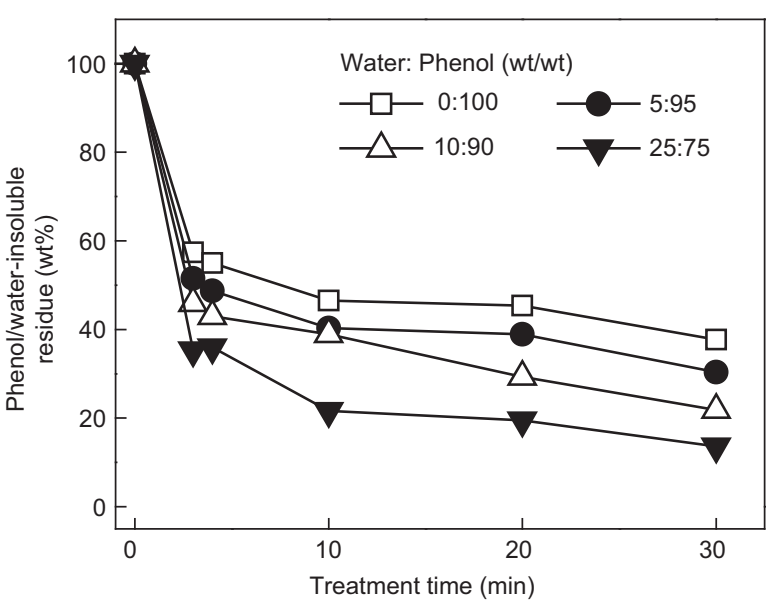

Figure 1 Changes in phenol/water-insoluble residue of Japanese beech as treated at $270^{\circ} \mathrm{C} / 1.8-3.1 \mathrm{MPa} / 3-30 \mathrm{~min}$ with different weight ratios of water added to phenol. 


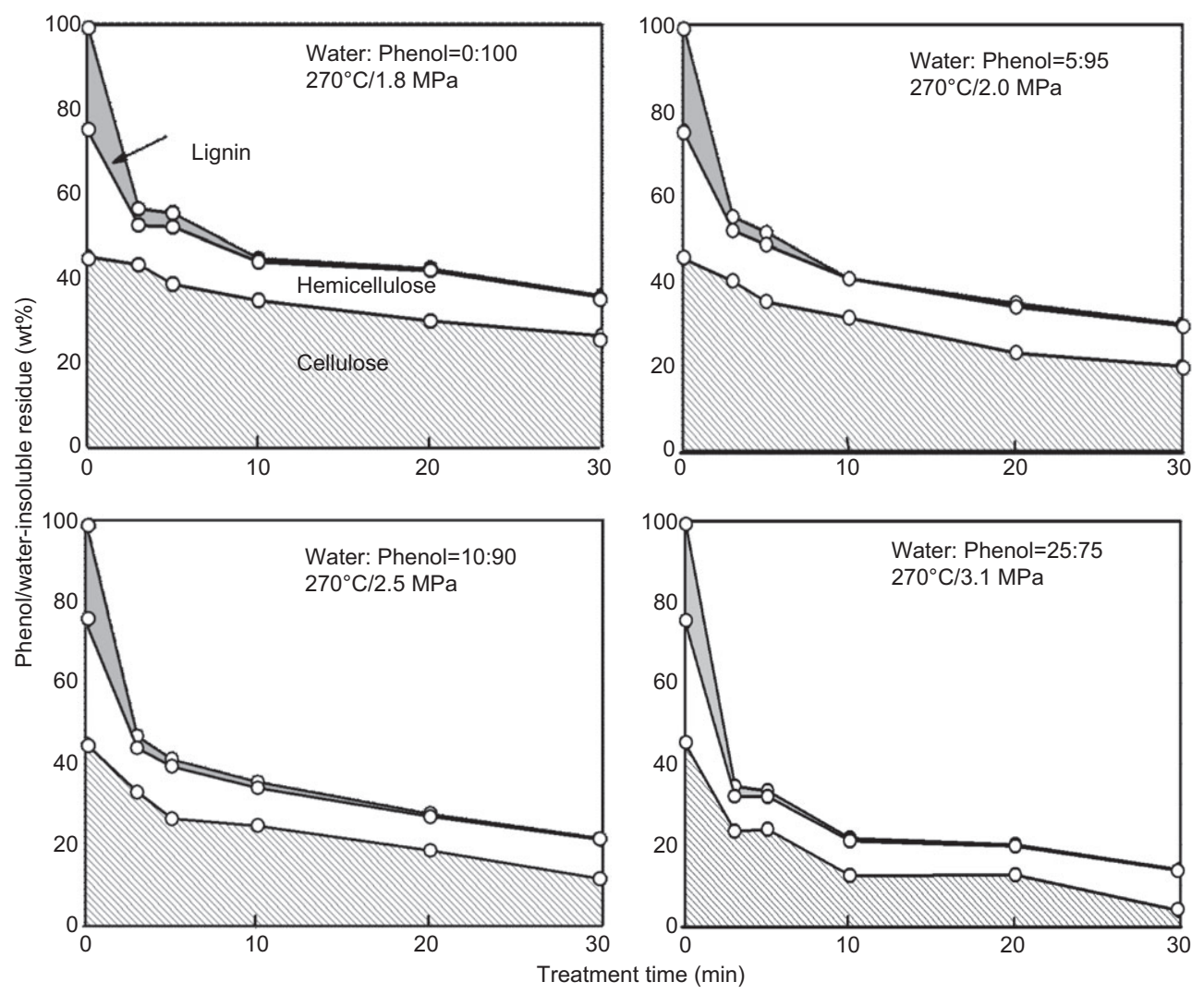

Figure 2 Changes in chemical composition of the phenol/water-insoluble residue of Japanese beech as treated at $270^{\circ} \mathrm{C} / 1.8-3.1 \mathrm{MPa} /$ 3-30 min with different weight ratios of water added to phenol.

Figure 2 shows the changes in the chemical composition of the phenol/water-insoluble residues (presented in Figure 1) as a function of treatment time and water/phenol ratios. Note that the pressure increased with more water in the reaction mixture from 1.8 to $3.1 \mathrm{MPa}$. The soluble moiety of the products is represented by the area above the lignin curve. At $270^{\circ} \mathrm{C} / 1.8 \mathrm{MPa} / 0: 100$, lignin was almost completely decomposed and liquefied within a few minutes, whereas hemicelluloses were liquefied only to some extent and cellulose was nearly not affected. At $270^{\circ} \mathrm{C} / 2.0$ $\mathrm{MPa} / 5: 95$, only a slight modification of the curves is visible. At the water/phenol ratios of 10:90 and 25:75, as the pressure is elevated to 2.5 and $3.1 \mathrm{MPa}$, respectively, the effects are more pronounced, that is, the hemicelluloses and cellulose were liquefied further with a complete liquefaction of lignin. The latter treatment conditions were obviously the best one for the liquefaction of wood.

\section{Effect of water in the mixture}

In the presence of water in phenol, both phenolysis and hydrolysis reactions are the driving forces behind the liquefaction. To study these effects, xylan, cellulose (Avicel), and MWL were liquefied under the same condition as presented in Table 1; the reaction time, however, was limited to $3 \mathrm{~min}$. It is clear that the phenolation of all cell wall components increased with increasing water/phenol ratios.

The combined phenol yields, calculated according to Eq. (1) and presented in Figure 3 as a function of treatment time, are increasing as expected. With a water/phenol ratio of 25:75, the maximum amount of combined phenol was achieved at all treatment times, whereas without water the combined phenol yield was always the smallest. Figure 4 shows the increasing combined phenol yields with increasing water amount in the mixture. The hydrolytic effect of water is due to the cleavage of $\beta-0-4$ and other ether linkages of lignin, in the course of which phenolic hydroxyl groups arise (Ehara et al. 2002). As observed in the supercritical methanol (Minami et al. 2003), the reactivity of phenolic structures of lignin toward phenolation is much higher than that of nonphenolic structures. This is the reason why phenolation was improved in the presence of water.

The amount of the phenolated wood, measured based on Eq. (2) (Table 2), is elevated with longer treatment times and higher ratios of water/phenol. The ratio of 25:75 gives 


\begin{tabular}{|c|c|c|c|c|c|}
\hline $\begin{array}{l}\text { Reaction condition } \\
\text { and sample }\end{array}$ & $\begin{array}{r}\text { Water } / \text { phenol } \\
\text { ratio (wt/wt) }\end{array}$ & $\begin{array}{r}\text { Phenol/water-insoluble } \\
\text { residue (wt\%) }\end{array}$ & $\begin{array}{r}\text { Phenol-soluble } \\
\text { portion (wt\%) }\end{array}$ & $\begin{array}{r}\text { Phenol in phenol } \\
\text { soluble portion }{ }^{\mathrm{a}}(\mathrm{wt} \%)\end{array}$ & $\begin{array}{l}\text { Phenol } \\
\text { per unit }\end{array}$ \\
\hline \multicolumn{6}{|l|}{$270^{\circ} \mathrm{C} / 1.8 \mathrm{MPa}$} \\
\hline Xylan & $0 / 100$ & 4.0 & 96.0 & 41.7 & 0.7 \\
\hline Avicel & $0 / 100$ & 81.2 & 18.8 & 1.6 & 0.2 \\
\hline MWL & $0 / 100$ & 7.7 & 92.3 & 126.7 & 2.2 \\
\hline Whole wood & $0 / 100$ & 57.4 & 42.6 & 98.8 & - \\
\hline \multicolumn{6}{|l|}{$270^{\circ} \mathrm{C} / 2.0 \mathrm{MPa}$} \\
\hline Xylan & $5 / 95$ & 1.3 & 98.7 & 50.8 & 0.8 \\
\hline Avicel & $5 / 95$ & 78.4 & 21.6 & 6.0 & 0.5 \\
\hline MWL & $5 / 95$ & 5.2 & 94.8 & 139.4 & 2.4 \\
\hline Whole wood & $5 / 95$ & 51.5 & 38.2 & 109.3 & - \\
\hline \multicolumn{6}{|l|}{$270^{\circ} \mathrm{C} / 2.5 \mathrm{MPa}$} \\
\hline Xylan & $10 / 90$ & 0 & 100.0 & 59.5 & 0.9 \\
\hline Avicel & $10 / 90$ & 72.0 & 28.0 & 11.1 & 0.7 \\
\hline MWL & $10 / 90$ & 2.8 & 97.2 & 151.1 & 2.5 \\
\hline Whole wood & $10 / 90$ & 45.9 & 39.2 & 126.4 & - \\
\hline \multicolumn{6}{|l|}{$270^{\circ} \mathrm{C} / 3.1 \mathrm{MPa}$} \\
\hline Xylan & $25 / 75$ & 0 & 100.0 & 70.3 & 1.1 \\
\hline Avicel & $25 / 75$ & 60.1 & 39.9 & 12.0 & 0.7 \\
\hline MWL & $25 / 75$ & 1.1 & 98.9 & 182.0 & 3.0 \\
\hline Whole wood & $25 / 75$ & 35.3 & 37.8 & 133.7 & - \\
\hline
\end{tabular}

Table 1 Reactivities of individual cell wall components as treated with subcritical phenol at $270^{\circ} \mathrm{C} / 3 \mathrm{~min}$ with different water/ phenol ratios.

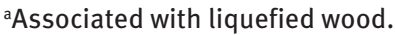

rise to the highest amount of phenolated wood at any particular treatment time.

\section{Characterization of the water-soluble fraction}

The critical point of phenol is at $421.2^{\circ} \mathrm{C} / 6.13 \mathrm{MPa}$ (Ambrose 1963), whereas that of water is $374^{\circ} \mathrm{C} / 22.1 \mathrm{MPa}$.

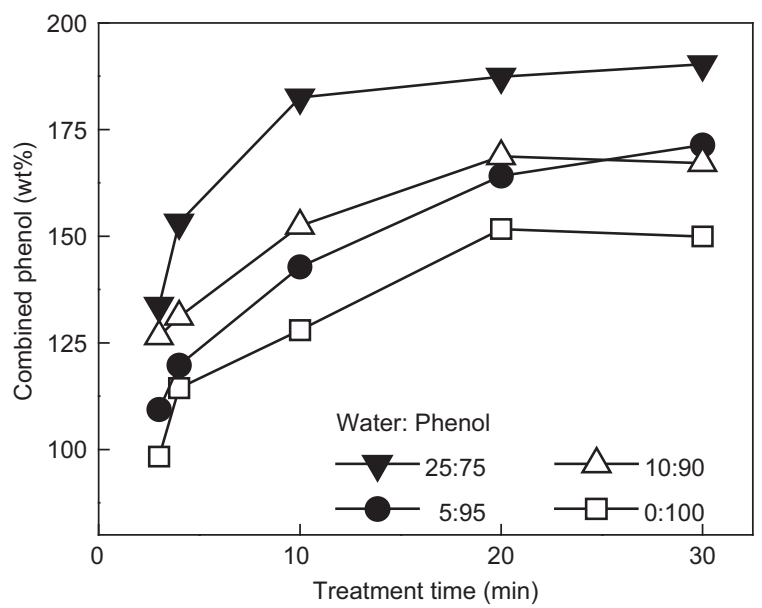

Figure 3 Changes in combined phenol in phenol-soluble portion of Japanese beech as treated at $270^{\circ} \mathrm{C} / 1.8-3.1 \mathrm{MPa} / 3-30 \mathrm{~min}$ with different weight ratios of water added to phenol.
Thus, supercritical conditions are too drastic. Therefore, the milder subcritical conditions were selected for the experiments of the present study as explained above.

As shown in Table 2, the water-soluble fractions of hemicelluloses do not contain lignin-type degradation products. Table 2 also demonstrates that cellulose and hemicelluloses are degraded to a higher extent if the water/phenol ratio is elevated. As pointed out above, this is due to the hydrolytic effect of water. Lignin-derived

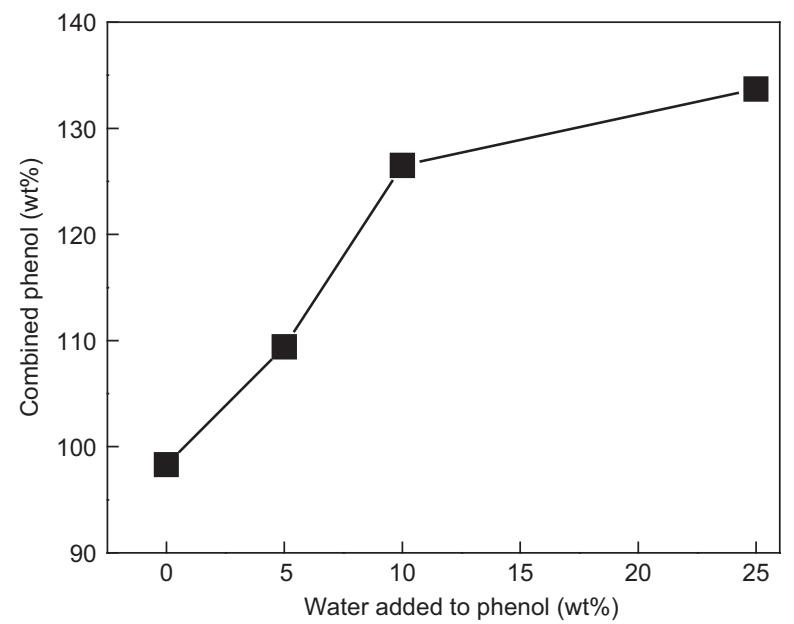

Figure 4 Changes in combined phenol in phenol-soluble portion of Japanese beech as treated at $270^{\circ} \mathrm{C} / 1.8-3.1 \mathrm{MPa} / 3 \mathrm{~min}$ with different weight ratios of water added to phenol. 


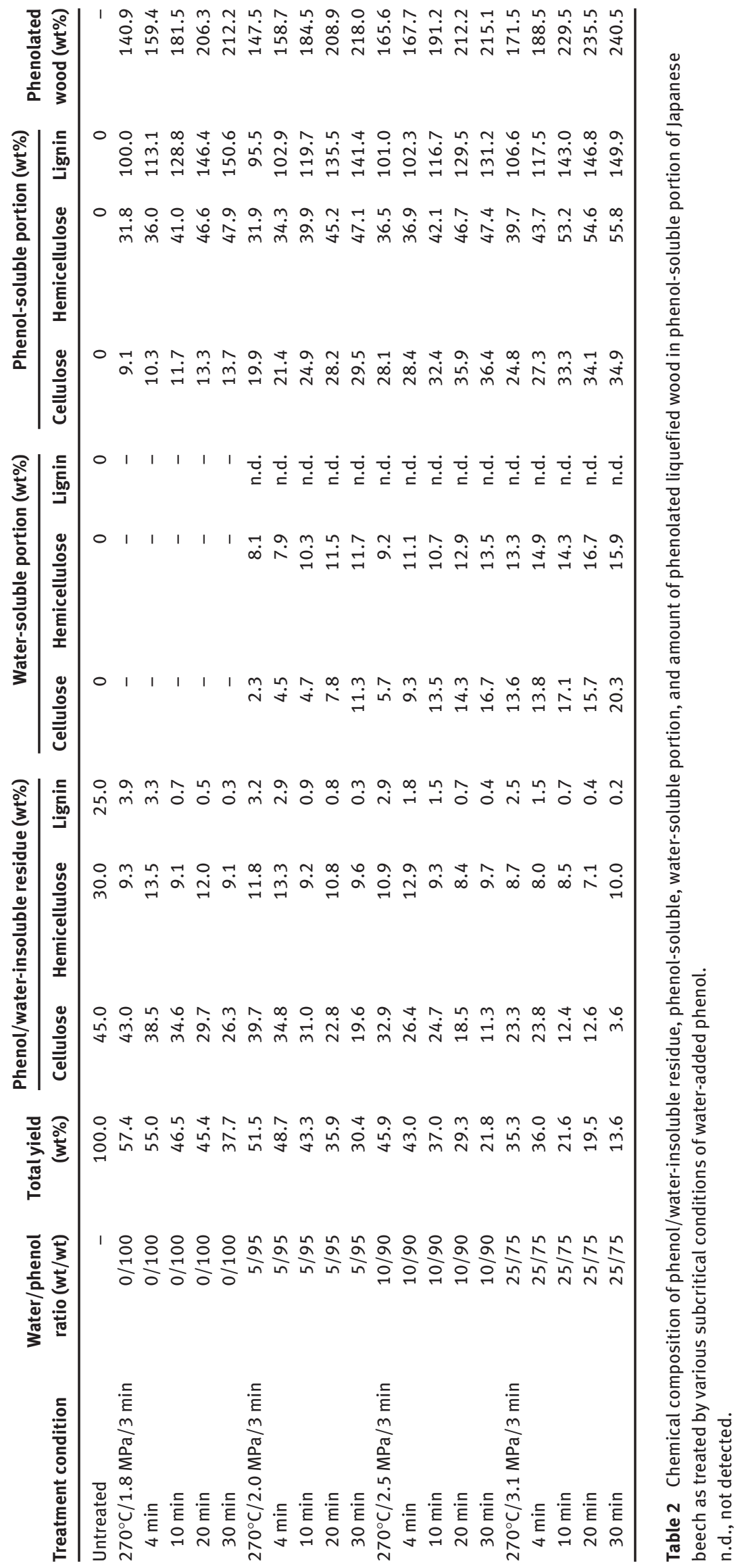


Liquefaction rate constant $k$

\begin{tabular}{lrrrrr} 
Reaction conditions & Water/phenol ratio (by wt) & Cellulose & Hemicelluloses & Lignin & Whole wood \\
\hline $270^{\circ} \mathrm{C} / 1.8 \mathrm{MPa}$ & $0 / 100$ & 0.0006 & 0.0033 & 0.0085 & 0.0025 \\
$270^{\circ} \mathrm{C} / 2.0 \mathrm{MPa}$ & $5 / 95$ & 0.0010 & 0.0034 & 0.0090 & 0.0030 \\
$270^{\circ} \mathrm{C} / 2.5 \mathrm{MPa}$ & $10 / 90$ & 0.0022 & 0.0035 & 0.0110 & 0.0035 \\
$270^{\circ} \mathrm{C} / 3.1 \mathrm{MPa}$ & $25 / 75$ & 0.0055 & 0.0055 & 0.0120 & 0.0042 \\
\hline
\end{tabular}

Table 3 Liquefaction rate constant for the major cell wall components of Japanese beech as treated by various subcritical conditions of water-added phenol.

products are hydrophobic and are phenolated in the course of the reactions, whereas the polysaccharides are mainly hydrolyzed and become water-soluble. In the phenol-soluble fraction, all wood constituents were phenolated.

\section{Kinetics of liquefaction}

The reaction rate of liquefaction was considered based on a first-order reaction scheme, where the rate constants were evaluated in the same manner as described by Yamazaki et al. (2006) and Mishra and Saka (2011) (Table 3). The rate constants are dependent on the treatment conditions and on the water/phenol ratios. At $270^{\circ} \mathrm{C} / 3.1 \mathrm{MPa} / 25: 75$, the rate constants for lignin, hemicelluloses, and cellulose are $0.012,0.0055$, and $0.0026 \mathrm{~kJ} \mathrm{~mol}^{-1}$, respectively. This order is valid also for the other liquefaction conditions. Accordingly, lignin reacts first during the liquefaction in the water/phenol mixtures.

\section{Conclusions}

The treatment of Japanese beech in water-added subcritical phenol at different ratios of water/phenol revealed that the degradation products of cellulose and hemicelluloses are in the water-soluble portion and those of lignin are in the phenol-soluble portion. The treatment at $270^{\circ} \mathrm{C} / 3.1 \mathrm{MPa}$ with a water/phenol ratio of $25: 75$ provides the best results. Expectedly, the yield of the combined phenol and phenolated wood increases with longer treatment times in the tested range between 3 and $30 \mathrm{~min}$. The same effect had the increment of the water content in the mixture in the range of 0 to $25 \%$. A high degree of phenolation was achieved at $270^{\circ} \mathrm{C} / 3.1 \mathrm{MPa} / 10$ min with a water/phenol ratio of 25:75 (182.5\% combined phenol and $229.5 \%$ phenolated wood) compared with the 190.3 and $240.5 \%$ yields, respectively, when the treatment time was extended to $30 \mathrm{~min}$. Considering the total energy balance, the shorter reaction time of approximately $10 \mathrm{~min}$ is more advantageous.

Acknowledgements: This work was accomplished under the financial support from the Kyoto University Global Center of Excellence Energy Science Program sponsored by the Ministry of Education, Science, Sports and Culture, Japan. This research work was also supported by the Grants-in-Aid for Scientific Research, JSPS, Scientific Research B (General) (No. 21380198, 2009.04-2012.03).

Received March 22, 2012; accepted September 25, 2012; previously published online October 23, 2012

\section{References}

Adschiri, T., Hirose, S., Malaluan, R., Arai, K. (1993) Noncatalytic conversion of cellulose in supercritical and subcritical water. J. Chem. Eng. Jpn. 26:676-680.

Alma, M.H., Yoshioka, M., Yao, Y., Shiraishi, N. (1995) Preparation and characterization of the phenolated wood using hydrochloric acid $(\mathrm{HCl})$ as a catalyst. Wood Sci. Technol. 30:39-47.

Alma, M.H., Maldas, D., Shiraishi, N. (1998a) Liquefaction of several biomass wastes into phenol in the presence of various alkalies and metallic salts as catalysts. J. Polym. Eng. 18:161-178.
Alma, M.H., Yoshioka, M., Yao, Y., Shiraishi, N. (1998b) Preparation of sulfuric acid-catalyzed phenolated wood resin. Wood Sci. Technol. 32:297-308.

Ambrose, D. (1963) Critical temperatures of some phenols and other organic compounds. Trans. Faraday Soc. 59:1988-1993.

Björkman, A. (1956) Studies on finely divided wood. Part 1. Extraction of lignin with neutral solvents. Svensk Papperstidning 59:477-485.

Demirbas, A. (2005) Bioethanol from cellulosic materials: a renewable motor fuel from biomass. Energy Sources 27:327-337. 
Ehara, K., Saka, S. (2005) Decomposition behavior of cellulose in supercritical water, subcritical water, and their combined treatments. J. Wood Sci. 51:148-153.

Ehara, K., Saka, S., Kawamoto, K. (2002) Characterization of the lignin-derived products from wood as treated in supercritical water. J. Wood Sci. 48:320-325.

Gütsch, J.S., Sixta, H. (2011) Purification of Eucalyptus globulus water prehydrolyzates using the HiTAC process (high-temperature adsorption on activated charcoal). Holzforschung 65:511-518.

Honglu, X., Tiejun, S. (2006) Wood liquefaction by ionic liquids. Holzforschung 60:509-512.

Hörhammer, H., Walton, S., van Heiningen, A. (2011) A larch based biorefinery: pre-extraction and extract fermentation to lactic acid. Holzforschung 65:491-496.

Kirsch, C., Zetzl, C., Smirnova, I. (2011) Development of an integrated thermal and enzymatic hydrolysis for lignocellulosic biomass in fixed-bed reactors. Holzforschung 65:483-489.

López, Y., Gullón, B., Puls, J., Parajó, J.C., Martín, C. (2011) Dilute acid pretreatment of starch-containing rice hulls for ethanol production. Holzforschung 65:467-473.

Maldas, D., Shiraishi, N. (1997) Liquefaction of biomass in the presence of phenol and $\mathrm{H}_{2} \mathrm{O}$ using alkalies and salts as the catalyst. Biomass Bioenergy 12:273-279.

McKendry, P. (2002) Energy production from biomass (part 2): conversion technologies. Bioresour. Technol. 83:47-54.

Minami, E., Saka, S. (2003) Comparison of the decomposition behaviors of hardwood and softwood in supercritical methanol. J. Wood Sci. 49:0073-0078.

Minami, E., Kawamoto, H., Saka, S. (2003) Reaction behavior of lignin in supercritical methanol as studied with lignin model compounds. J. Wood Sci. 49:158-165.

Mishra, G., Saka, S. (2010) Liquefaction behaviors of Japanese beech as treated in subcritical phenol. In: Zero-Carbon Energy Kyoto 2010. Ed. Yao, T. Springer, Japan. pp. 147-152.

Mishra, G., Saka, S. (2011) Kinetic behavior of liquefaction of Japanese beech in subcritical phenol. Bioresour. Technol. 102:10946-10950.

Mishra, G., Saka, S. (2012) Effects of various solvents on precipitation of phenolated products from Japanese beech as treated by subcritical phenol. In: Zero-Carbon Energy Kyoto
2011, Green Energy and Technology. Ed. Yao, T. Springer, Japan. pp. 139-144.

Nakamura, A., Miyafuji, H., Saka, S., Mori, M., Takahashi, H. (2010) Recovery of cellulose and xylan liquefied in ionic liquids by precipitation in anti-solvents. Holzforschung 64:77-79.

Phaiboonsilpa, N., Saka, S. (2011) Effect of acetic acid addition on chemical conversion of woods as treated by semi-flow hot-compressed water. Holzforschung 65:667-672.

Phaiboonsilpa, N., Tamunaidu, P., Saka, S. (2011) Two-step hydrolysis of nipa (Nypa fruticans) frond as treated by semi-flow hot-compressed water. Holzforschung 65:659-666.

Pu, S., Shiraishi, N. (1993) Liquefaction of wood without a catalyst I: time course of wood liquefaction with phenols and effects of wood/phenol ratios. Mokuzai Gakkaishi 39:446-452.

Saka, S. (2006) Recent progress in supercritical fluid science for biofuel production from woody biomass. For. Stud. China 8:9-15.

Saka, S., Konishi, R. (2001) Chemical Conversion of Biomass Resources to Useful Chemicals and Fuels by Supercritical Water Treatment. Progress in Thermochemical Biomass Conversion. Blackwell Science Ltd., Oxford. pp. 1338-1348.

Schütt, F., Puls, J., Saake, B. (2011) Optimization of steam pretreatment conditions for enzymatic hydrolysis of poplar wood. Holzforschung 65:453-459.

Soria, A.J., McDonald, A.G., He, B.B. (2008a) Wood solubilization and depolymerization by supercritical methanol. Part 2: analysis of methanol soluble compounds. Holzforschung 62:409-416.

Soria, A.J., McDonald, A.G., Shook, S.R. (2008b) Wood solubilization and depolymerization using supercritical methanol. Part 1: process optimization and analysis of methanol insoluble components (bio-char). Holzforschung 62:402-408.

Testova, L., Chong, S.-L., Tenkanen, M., Sixta, H. (2011) Autohydrolysis of birch wood. Holzforschung 65:535-542.

Toor, S.S., Rosendahl, L., Rudolf, A. (2011) Hydrothermal liquefaction of biomass: a review of subcritical water technologies. Energy 36:2328-2342.

Viell, J., Marquardt, W. (2011) Disintegration and dissolution kinetics of wood chips in ionic liquids. Holzforschung 65:519-525.

Yamazaki, J., Minami, E., Saka, S. (2006) Liquefaction of beech wood in various supercritical alcohols. J. Wood Sci. 52: 527-532. 
Copyright of Holzforschung: International Journal of the Biology, Chemistry, Physics, \& Technology of Wood is the property of De Gruyter and its content may not be copied or emailed to multiple sites or posted to a listserv without the copyright holder's express written permission. However, users may print, download, or email articles for individual use. 